April 2010

\title{
Review Essay: Old Concerns and New Plays in the Theater of Genocide
}

Robert Skloot

Follow this and additional works at: https://digitalcommons.usf.edu/gsp

\section{Recommended Citation}

Skloot, Robert (2010) "Review Essay: Old Concerns and New Plays in the Theater of Genocide," Genocide Studies and Prevention: An International Journal: Vol. 5: Iss. 1: Article 8.

Available at: https://digitalcommons.usf.edu/gsp/vol5/iss1/8

This Document is brought to you for free and open access by the Open Access Journals at Digital Commons @ University of South Florida. It has been accepted for inclusion in Genocide Studies and Prevention: An International Journal by an authorized editor of Digital Commons @ University of South Florida. For more information, please contact digitalcommons@usf.edu. 


\title{
Review Essay: Old Concerns and New Plays in the Theater of Genocide ${ }^{1}$
}

\author{
Robert Skloot \\ University of Wisconsin-Madison
}

This review essay describes and evaluates the theatrical strategies and dramatic contributions of seven stage productions that represent recent examples of the Theater of Genocide. Taken together, they deal with Bosnia (Roel Adam), Cambodia (Catherine Filloux), Congo (Lynn Nottage), Darfur (Winter Miller), and Rwanda (Erik Ehn, J.T. Rogers and Dorcey Rugamba). The author focuses on a number of major issues in theater criticism: (a) the nature and effectiveness of empathy, (b) the use of white, Western characters to serve as surrogates for white, Western audiences' emotional investment in the stories, and (c) the artistic use of historical events for theatrical, humane purposes. The essay strongly articulates the need of genocide scholarship to include discussions of the arts as it addresses the universal problem of human violence and the wholesale murder of innocents.

Key words: empathy, theater of genocide, staging atrocity

When my edited anthology The Theatre of Genocide: Four Plays About Mass Murder in Rwanda, Bosnia, Cambodia and Armenia was published in 2008, I took upon myself the task of identifying a number of plays that expressed a variety of thematic, stylistic, aesthetic, and ethical concerns by playwrights writing about genocide. The plays I selected were just a few available in English for publication that I knew about. Now, two years later, there are a number of other valuable scripts, some new and some new to me, that might find their way into a second volume, were there to be one.

To be sure, one purpose of publishing the collection was to bring to the attention of readers and theater producers selected plays that deserve study and production, and thus, to a larger purpose, alert them to the existence of a way to discuss genocide that departs from the more traditional methods of inquiry. Those traditional methods, the property of the social sciences, overlook or purposefully dismiss the power of the arts to add to the genocidal conversation. Simply put, those who have a negative bias toward things attached to idealism or redolent of emotion, who hold the arts in less esteem than the "hard" disciplines, and who hold fast to the grand processes of history or the rigid categories of personality, often greet as starry-eyed, distractive, untrustworthy, or worse the ways art reveals knowledge of a different kind than they are used to or comfortable with. I have written about this at greater length elsewhere, and I confess to riding this hobbyhorse into a number of conferences devoted to the Holocaust or genocide. For example, "plays do things to people. What the theatre can provide uniquely is a connection between human beings and among groups through the creation of empathy. It is a connection that, however brief, creates visible, remarkable humane possibilities..."

It was my stressing of the salutary, indeed transformative possibilities of empathy in my Introduction to The Theatre of Genocide that most concerned a reviewer

Robert Skloot, "Old Concerns and New Plays in the Theater of Genocide." Genocide Studies and Prevention 5, 1 (April 2010): 114-120. (C) 2010 Genocide Studies and Prevention. doi:10.3138/gsp.5.1.114 
of the book, who suggested that it would be better to use a term like witness (after Beckett's drama), and advocated being more mindful of empathy's limits, in particular because of its tendency to create feeling rather than encouraging doing, and because empathy may be inappropriate to the more necessary task of bearing witness. ${ }^{3}$ Nonetheless, I want to reaffirm my positive sense of empathy's possibilities, and advance the idea that the concept could benefit from additional discussion. I also want to make clear that the empathic response is seen not only in the connection of audience member to stage character (both victim and perpetrator) but also in "connecting" the audience members as well. Here are the words of Simon McBurney, who last year directed an acclaimed production in New York of Arthur Miller's All My Sons, discussing what he calls "the collective imagination":

At that moment we understand the lie that what we think is only our own, that our internal lives are only our own. At that point, our collective imaginations become one imagination and my internal life becomes the same as your internal life, which is what Aristotle understood when he analyzed tragedy. It's a collective act in which we collectively understand something about being a community together. The moment that we understand that, feel it, we feel a kind of responsibility in which we must collectively help and take responsibility for each other. ${ }^{4}$

Remembering, of course, that the responses to individual productions (indeed, to individual performances) may differ greatly, it was clear to me that on a night in February of last year when I saw Ruined-Lynn Nottage's Pulitzer Prize-winning play about women caught in the violent struggle in Congo-that an empathetic connection between audience and character was successfully accomplished, which accounts, in part, for the extension of the play's New York run. Ruined is one of the new and important scripts that has been added to the growing list of plays comprising the theater of genocide. ${ }^{5}$

I confess to believing that these empathic occasions are easier to achieve in the productions of plays written in the style of realism, as Nottage's play mostly is. But the three plays of genocide I will mention below are stylistically very different from realism, and their premises are also divergent one from the others. They all deserve to be tested in performance, however, and may find success for any of a number of reasons.

A second matter of concern that I have thought about over recent months involves the relationship between the protagonists who are citizens of the West, and especially the United States, and their antagonists, who consist of the "native" or local populations with whom they interact. A distinguishing feature of Ruined, or at least the one that I find most courageous on the playwright's part, is that her protagonists, indeed most of her cast, are only people of Congo itself. (There is one white outsider in a small role.) Nottage, one of America's best playwrights and an African American, tells these abused women's experiences without having their lives and fate determined by colonial intervention and, significantly, without reference to a Western character through whom and against whom their stories are told.

This approach and achievement is different from two of the genocide plays in my anthology that share an important similarity in their geographic/racial surrogacy. In Catherine Filloux' Silence of God, the protagonist is Sarah Holtzman, a white American journalist on the trail of Pol Pot and in search of a way to "crack the puzzle," that is, to come to comprehend why evil flourishes. Although her experience is paired with that of her poet-lover, a survivor of the Cambodian genocide, the plot of the play is moved along in large part because of her professional commitment to 
the Western press and to Cambodia's cultural mysteries that she tries to penetrate as an outsider living and working, no matter how sympathetically, in the "Far East." It seems clear that focusing on the psychological confusion and physical dislocation of Sarah is intended to enhance the empathic connection between First World audiences and Sarah as she struggles for clarity of purpose and understanding of herself and others.

Erik Ehn's play Maria Kizito utilizes a similar strategy. In his play, our introduction to the Rwandan genocide and our guide through its atrocities and aftermath is Teresa, the white American novice whose understanding of the genocide and Catholicism's complicity in it define the story of a journey into the hearts of Africa and of human darkness. In addition, as a witness-observer to the trial of the Rwandese nuns Sisters Maria and Beatrice, Theresa is our surrogate in the search for justice as well as our compatriot in the often-confusing negotiation of Rwandese politics and society. When justice is uncertain and the culture is opaque, having a young white woman to serve as a conduit for the audience's narrative and empathic connection is a welcome strategy in Western theaters. (I confess to believing that theater in the United States, at least the kind of theater where these plays are most likely to have productions, is largely a white, middle-class affair.)

Another example of the identical West-East trope is used by J.T. Rogers in his play The Overwhelming, first performed in London in May 2006. ${ }^{6}$ In that play, the white protagonist Jack Exley, an American professor contending with tenure issues, confronts the terror of the Rwandan genocide and how his search to do the right thing for a Rwandan colleague is compromised by his ignorance, his innocence, his domestic situation, and by that dark heart of violence. Rogers' play is much more satirical than Filloux' or Ehn's, but his internal and external conflicts are intended to reflect the painful conundrums of an African culture and an African genocide when seen through the eyes of a Western professor. The violent action of The Overwhelming reaches its powerful climax in the moment Exley is presented with the moral conundrum: only betraying a friend to a certain and horrible death can save Exley's family. Exley's "choice" frames a stunning ethical problem, one often seen in plays of the Holocaust.

Similarly, in Winter Miller's In Darfur (2008), the protagonist (also a white journalist), Maryka Lindstrom, is working in Darfur while trying to keep secret her friend Hawa's identity to protect her from further atrocity. Nonetheless, she has to satisfy the demands of her far-away editor at The New York Times with dramatic, and for Hawa, life-threatening facts. Miller's play analyzes the personal and professional ethical problems of First World journalists and NGO aid workers in a Third World place of genocide, and finds no answer to stopping the violence and terror that characterizes it, though she is deeply committed to her humane tasks. In both Rogers' play and Miller's, audiences are asked to listen to the substantial use of nonEnglish languages to provide a theatrical, geographical specificity to the productions-Arabic and French in In Darfur, and Kinyarwanda and French (and even a little Spanish) in The Overwhelming.

Three other new plays deserve mention for how they explore and exploit the concerns with empathy, violence, culture, and language. Roel Adam's play On the Other Side premiered in the Netherlands in 2005. Of first importance, the play is meant for young people, what we call "theater for young audiences." It tells the story of the 1993 destruction of the Stari Most, the Old Bridge in Mostar, Bosnia, over the Neretva River, which was intentionally blown apart during the civil war. The 500year-old bridge was a symbol of the historic and proud connection between the 
Muslim and Christian sections of the city. Can bridges be rebuilt? Friendships restored? Memories buried? These are the three questions asked in the prefatory note "About the Play."7

On the Other Side's protagonists are two eleven-year-old children, the Muslim boy Zakka and the Christian girl Hanna. Much of the play is presented as a kind of cartoon, with outlandish farcical episodes (including cross-dressing) that emphasize the humor with which this tragic tale is told. At times, the children use hand puppets to develop the plot, which focuses on the antagonism between the Old Bridge and the River, respectively portrayed by Zakka's father and Hanna's mother. The play begins at the end of the prologue when the bridge, constructed of simple plywood and white rocks, is knocked down. The play's action ends just before a brief, sad, and somewhat ambiguous epilogue, with the Bridge and the River dancing and the children beginning to rebuild the Bridge.

Adam's play contains both hope and despair. It is distinguished by its concern with children (and children survivors) and told as much for them as for adults. It refuses to neglect the violence of war and the tragic human toll war takes (the representative agent of ethnic killing in the play is the village Teacher), but in form and message it tries to adhere to the mission of traditional comedy: the repair of broken relationships and the reconciliation of warring parties. Thus, the central action of the play involves the comic reconciliation of the Bridge and the River, who have disguised themselves and are revealed by theatrical tricks of costume and language. The player of the trick is the Engineer, a master clown with the name of M. La Paix who speaks an amalgam of Spanish, French, and German ... but not Bosnian. Thus, the play converts the nasty recent history of atrocity into a sometimes humorous fable, and its child protagonists' rich claim on our complicit imaginations, in relating their story of violence and dislocation, concludes tragicomically. The play is a distinctive and successful example of the theater of genocide.

Catherine Filloux is the author of a number of plays that focus on the experience of genocide, including several located in Cambodia; her Silence of God is mentioned above. In the spring of 2008, the opera Where Elephants Weep, for which she contributed the libretto and for which Him Sophy provided the music, premiered in America in Lowell, Massachusetts, home to a large Cambodian community. Where Elephants Weep had its debut in Phnom Penh in December 2007, and has been called "the firstknown contemporary Cambodian rock-opera."8

In fact, the adjective "post-genocide" can also be added to this description. The opera was commissioned by Cambodian Living Arts organization with the intention of revitalizing, even recreating the nearly extinguished Cambodian culture that was condemned by the Khmer Rouge, who advanced their savage agrarian revolution with the murder of the cosmopolitan and formally educated, including many Cambodian artists. The project's design is to combine a classical culture and mythology with the most modern of dance and musical forms, creating a vibrant and reciprocally enhancing integration of, for example, shadow puppets and classical dance with rap music and break dancing. Filloux was quoted in a CNN interview that she hoped to bring our understanding of post-genocide Cambodia into a light that would show "the resilience of spirit of Cambodian people ... the enormous challenges they have faced and how their art and their sensibility and their spirituality can utterly transform them.",9

And, of course, the aim of such theater is to transform us as well. Unlike the strategy of several of the plays described earlier, we do not perceive contemporary Cambodia through the eyes of a Westerner, but through the eyes of Westernized 
Cambodians, in particular of Sam and Dara, two men who were child soldiers in Pol Pot's army. They fled to Thai refugee camps and eventually immigrated to the United States, where they grew into Cambodian Americans. The theme of the play asserts the complexities and clashes of contending cultures internalized and reintegrated into the lives of refugee-perpetrators of violence and, of great significance, illustrates how the arts of music, dance, and theater can create a new, life-affirming synthesis despite the tragic history that attaches itself to Cambodia's rebirth. (Similarly, Hawa in Miller's play finds personal intellectual and emotional sustenance in Western literature.)

Filloux' libretto is deeply influenced by what we call "the Broadway musical." The two lovers who engage our attention are as theatrically recognizable as previous tragic couples on the Western stage. In the script, the actor-singers are described in ways that display the vocal signatures and styles of American musical theater from the middle of last century to the present. We see and hear classical Cambodian rituals, iconography, dances, and musical instruments as they affect the characters of the opera, who are our surrogates for cultural instruction; I surmise that the performances in Phnom Penh created the same intercultural dynamic in the reverse. Of crucial importance is the fact that a number of the characters perform their parts in Khmer, so that we can hear the language of Cambodia spoken and sung in a stylistically complicated and integrated occasion that performs the very theme (the rebirth of Cambodian culture) that the opera is articulating. Where Elephants Weep is a unique contribution to the theater of genocide, deserving of a wide audience.

The last production (and the shortest) played in Chicago this spring, although I saw it in London in the fall of 2007. It is also the most intellectually complicated and risky, dealing as it does not with one genocide but with two. The length is important because at eighty minutes, the production contains hardly a quarter of the full text of Peter Weiss' docudrama from 1965, The Investigation (Die Ermittlung), a play that uses for its dialogue the verbatim transcript of the 1964 Frankfurt Auschwitz trials. The production owes its complexity and controversy to the fact that it was performed by a company of Rwandan actors, who speak mostly in French throughout the play. The Urwintore Company is led by Dorcy Rugamba, who shortened the original play and directed it, along with Isabelle Gyselinx. His work is based on the conviction that a play about the Holocaust, when transformed into a Rwandan context, can shed new and important light on the historical and psychological meanings of the genocide of 1994. In Rugamba's own words,

In many ways, it's exactly the right piece for us now. It's a play about two versions of history: the victims' and the executioners'. The Frankfurt trials were the first time that Germans confronted and judged Germans in the aftermath of a national trauma; Rwanda is now deep in the same process with our Gacaca village tribunals ... So, watching as a Rwandan, it doesn't matter if you're the son of a killer or of a victim, because the play doesn't say: I accuse my neighbor's father. The values are more universal. ${ }^{10}$

In fact, much of the problem with the production lay in whether the experience performed lost or gained from the attempt to make itself universal, "to tell one story while using another," in the words of one critic, who went on to describe the main problem with this approach as being that "you could make an argument that, while such an appropriation is surely an inspired move in front of African audiences, European and American audiences still know so little about the events of 1994 that this travelling Rwandan company would have been better using its own words and telling 
its own stories."11 Of course, evidence of "universality" has long been a feature of Holocaust drama, beginning with the glossing over (some say expunging) of Anne Frank's Jewishness in the first play made from her diary in 1956.

The stage I saw the production on was bare, and it had several levels. Six men and one woman played the parts of The Investigation's several dozen perpetrators and victims, in emotional and rhetorically elevated performances. The French dialog was translated and projected onto screens on either side of the stage, but about twothirds of the way through the performance, the actors performed a scene in Kinyarwanda. There was an astonishing shock as the performance actually located itself in the Rwandan experience through the language switch rather than through genocidal analogy. Here, however, is raised another complex and worrisome question about language. French is the colonial language of Rwanda, and the Belgians who spoke it used it to create the bogus ethnic categories that were at the exterminatory heart of the genocide. Curiously, the German of Weiss' original is also a colonial language, and the object of the language's violence (so efficiently bureaucratic as many have remarked) were fellow citizens who spoke it fluently from birth. Here, surely, the practicalities of international, First World performing are a crucial determinant to the public presentation of a work of art, despite the fact that most of the London and Chicago audiences didn't speak French.

Further, to have the victims and perpetrators speak each other's testimony confuses the exterminatory responsibility for the Jewish genocide that Weiss' text unmistakably placed on the Germans (who were, according to Weiss, working to the unavoidable purposes of the capitalist system). ${ }^{12}$ In the Rwandan genocide, the overwhelming evidence that the more numerous Hutus murdered the Tutsis (although there were exceptions where the reverse was true) is the crucial fact of the annihilation, and to confuse this attribution of blame and responsibility is to damage the premise on which this and all genocide history is naturally based. Though it is true that both Hutu and Tutsi spoke the same language, a universalizing cliché like "How can we get along if we don't speak the same language?" adds only an ironic touch to such a disputatious and accusatory original text. Even if victims and perpetrators sounded the same, we know they did not act the same.

A review of the London production referred to the production's "depressing conclusion" and quoted a line from the play: "the society that produced the [Nazi extermination] camps is our society." 13 Well, yes and no. We know that certain events in history have similarities and commonalities with other events, but they have differences, too. Thus, for example, there were no gas chambers in Rwanda, nor were there machetes in Nazi Germany. Surely it is important that these differences are acknowledged before the universalizing process occurs, a process that is fraught with a historical complexity, against which clear distinctions can provide knowledge if not clarity. What the knowledge cannot provide is empathy, which the multiplicity of an actor's roles that include both victims and perpetrators makes additionally difficult. In sum, the production of The Investigation moves us further away from the Rwandan genocide, although the intention was to move us closer; the production did nothing to fill in the enormous gaps in our knowing more about the African genocides of the twentieth century. Thus, despite the powerful voices and unmistakable bodies of the Rwandan actors, I'm not sure the production asked enough of itself or of the audience.

From this brief and highly subjective overview of recent examples of the theater of genocide, it is possible to conclude that the aesthetic challenges seen fifty years ago in the theater of the Holocaust still remain and know of no easy solution. What- 
ever script concerning genocide we examine, we confront such issues as the creation and effects of empathy, the ubiquity of human violence, the complexity of language and the translations of historical facts, the attraction of universalizing experience, the disparity in knowledge and resources within national and group populations, and the varying needs of those groups in confronting historical atrocity and creating a favorable cultural legacy. Even so, we are lucky that the conversation is ongoing and that the theater, by no means alone, is carrying it on for us.

\section{Notes}

1. This review article is adapted from a paper delivered at the IAGS Conference in Arlington, VA, in June 2009.

2. See Robert Skloot, "Introduction," in If The Whole Body Dies: Raphael Lemkin and the Treaty Against Genocide (Madison, WI: Parallel Press, 2006), 6.

3. See review by Jean Graham-Jones, Human Rights Quarterly 30 (August 2008): 808-10.

4. Erik Piepenburg, "An Expert in Audacity Tries Arthur Miller," The New York Times, 26 October 2008, AR6, http://www.nytimes.com/2008/10/26/theater/26piep.html (accessed 14 January 2010). For a more complete discussion of empathy in the theater, see Robert Skloot, "Where Does It Hurt?' Genocide, the Theatre and the Human Body," Theatre Research International 23 (Spring 1998): 51-58.

5. Lynn Notage, Ruined (New York: Theatre Communications Group, 2009).

6. J.T. Rogers, The Overwhelming: A Play (New York: Faber \& Faber, 2006).

7. Manon van de Water's English translation is in Manon van de Water, ed., Dutch Theatre for Children: Three Contemporary Plays (Woodstock, IL: Dramatic Publishing, 2009).

8. "About Us," Where Elephants Weep project homepage, http://www.whereelephantsweep. net/inner/about_mission.html (accessed 14 January 2010).

9. Miranda Leitsinger, "Cambodia's First Rock Opera Hopes Its Stage Will Be a Bridge," CNN.com, 4 December 2008, http://edition.cnn.com/2008/WORLD/asiapcf/11/25/cambodia. opera/index.html (accessed 14 January 2010).

10. “Scar Tissue" (interview with Jon Hensley), The Guardian, 31 October 2009.

11. Chris Jones, "Investigation at Chicago Shakes: Holocaust Horrors Transplanted to Rwanda, with Chilling Effects," Chicago Tribune, 25 January 2009, http://archives.chicagotribune. com/2009/jan/25/entertainment/chi-investigation-ovn-0125jan25 (accessed 14 January 2010).

12. A recent overview of the purposes and creative process of Weiss's "documentary" play can be found in Gene Plunka, "Marxism and the Holocaust," in Holocaust Drama: The Theatre of Atrocity, 114-31 (New York: Cambridge University Press, 2009). It's important to note that Rugamba seems to see nothing of use for his production in Weiss's Marxist bias.

13. Nicholas de Jongh, "A Long, Cool Look at Genocide," The Evening Standard, 2 November 2007, archived by Urwintore, http://urwintore.wordpress.com/presse/ (accessed 14 January 2010). 